\title{
Current status and future perspectives for localizing the solar photovoltaic industry in the Kingdom of Saudi Arabia
}

\author{
Zaid S. AlOtaibi ${ }^{1}$. Hussam I. Khonkar ${ }^{1} \cdot$ Ahmed O. AlAmoudi $^{1}$ · Saad H. Alqahtani ${ }^{1}$
}

Received: 9 August 2019 / Accepted: 20 November 2019 / Published online: 22 February 2020

(c) The Author(s) 2020

\begin{abstract}
Saudi Arabia has developed Saudi Vision 2030, an ambitious plan to reduce the country's dependence on oil by supporting promising private energy organizations and by developing opportunities that contributes to the national economy. In the manufacturing sector, the government is encouraging technology transfers in the renewable energy industries. It is expected to result in the localization of significant parts of the renewable energy value chain in Saudi Arabia. Solar energy systems are proven renewable energy source globally and domestically, it has its long and vast share of experience, from operations and maintenance, to solar data monitoring and gathering. Wide areas had been identified, where this technology can be highly installed and integrated. Components can be manufactured from locally available raw materials to achieve the final products. This study analyzed the key elements of the value chain for producing crystalline silicon solar photovoltaic systems. This paper presents recommendations for localizing this industry in the Kingdom of Saudi Arabia to align with the goals of Saudi Vision 2030. Although these recommendations are based on the environmental conditions of Saudi Arabia, such are also highly relevant for further application to other countries in the Middle East and North Africa region, where widespread energy transitions from fossil fuels to renewable resources are already taking place.
\end{abstract}

Keywords Crystalline silicon · Localization · Photovoltaic (PV) · Cost breakdown · Saudi Vision $2030 \cdot$ Value chain

\section{Introduction}

Renewable energy resources have been gaining increasing attention globally as the world shifts from its reliance on fossil fuels to sustainable energy systems. The recent rapid growth of renewable resources in the electricity sector has been boosted by several factors, including the significant decrease in system costs and the formulation of dedicated national policies and initiatives for adopting renewable energy [1]. Consequently, new opportunities for centralized

Zaid S. AlOtaibi

zalotaibi@kacst.edu.sa

Hussam I. Khonkar

khonkar@kacst.edu.sa

Ahmed O. AlAmoudi

alamoudi@kacst.edu.sa

Saad H. Alqahtani

shalqhtani@kacst.edu.sa

1 Energy and Water Research Institute, King Abdulaziz City for Science and Technology, P.O. Box 6086, Riyadh 11442, Saudi Arabia and distributed renewable energy markets are likely to appear globally [2]. High-level agreements have been made by the $\mathrm{G} 7$ and $\mathrm{G} 20$ governments in an attempt to accelerate access to renewable energy and promote energy efficiency on the demand side. The United Nations General Assembly adopted clear sustainable development goals that promote sustainable energy projects [3]. The European Union is committed in reducing greenhouse gas (GHG) emissions to $80-95 \%$ of 1990 levels by 2050 , as they recognize the obligation of developed countries to make necessary reductions [4]. In addition, the European Council adopted ambitious energy and climate change objectives for 2030 to reduce GHG emissions by $40 \%$ compared to 1990 levels, which require increasing the contribution of renewable energy to at least $27 \%$ of consumption [5]. The United Kingdom has addressed the importance of bridging the research gap in the field of sustainable energy technologies. Uncertainty analysis results show that an $80 \%$ reduction in GHG emissions is achieved with an installed generation capacities of $100 \mathrm{GW}$ and $130 \mathrm{GW}$ by 2050 [6]. The world installed a record number of new solar power projects in 2017, more than the net additions of coal, gas, and nuclear plants put 
together. China has been the leading destination for renewable energy investment, accounting for 45 percent of the global investment. It plans to achieve $16 \%$ renewables by 2030, while some studies reveal that China should be able to reach $26 \%$ renewable energy by 2030 and $60 \%$ renewable energy and $86 \%$ renewable electricity by 2050 [7].

In the Middle East and North African (MENA) region, transition from oil-based economies to renewable energy is increasingly discussed and implemented, driven by both political and environmental incentives. In the Gulf Cooperation Council (GCC) countries, renewable energy projects and initiatives have grown alongside tangible developments in the local value chain. The 2030 plans of GCC countries could save around 354 million of barrels of oil equivalent and could cut $\mathrm{CO}_{2}$ emissions by $22 \%$ [8]. Various energy mix scenarios are being planned or implemented across the GCC countries, which include renewable energy, nuclear energy, and energy efficiency measures. In some countries, such as the Kingdom of Saudi Arabia (KSA) and the United Arab Emirates (UAE), specialized bodies for renewables and energy efficiency have been established to facilitate the energy transition [9]. The United Arab Emirates, for example, recorded an astounding 29-fold increase in renewable energy investment in 2017. Figure 1 shows the renewable energy plans and targets in the KSA, which include some recent modifications following the development of Saudi Vision 2030, which has increased the focus on, including renewable resources in the national energy mix. Solar energy is the most abundant renewable energy resource in the kingdom. Several solar photovoltaic (PV) projects have recently been announced with the aim of supplying electricity with very competitive costs [10].

The electricity demand of KSA has grown very rapidly, where an investment of more than 33 billion Saudi Riyals to achieve an annual growth rate of about $6 \%$ over the next decade [11] has been made. The Saudi government has imposed electricity tariffs and generated energy efficiency measures to reduce the electricity demand that will decrease

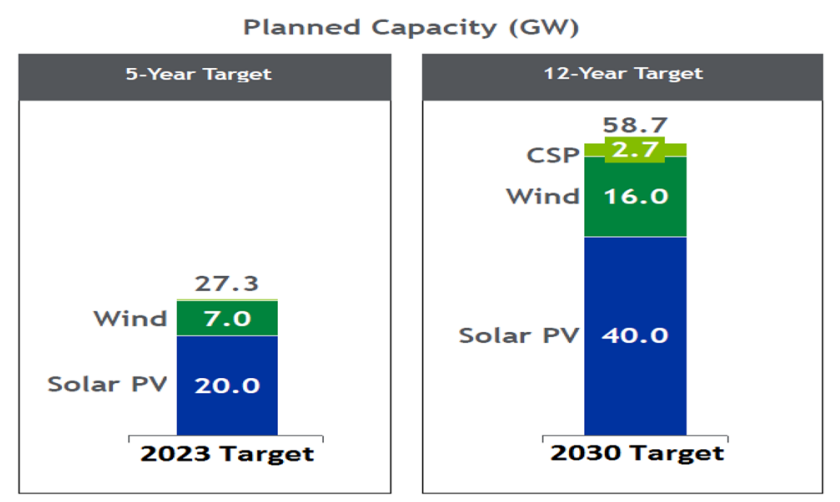

the electricity peak load. The electricity load curve peaks at midday, which is similar to the peak of the solar irradiance curve. It is, therefore, a good strategic choice to produce electricity from solar energy, as it is a country with abundant sunshine. The solar energy sector is growing in response to the Saudi Vision 2030 plans for economic diversification. As shown in Fig. 1, KSA is committed to installing $27.3 \mathrm{GW}$ of renewable energy by 2023 , most of which, $20 \mathrm{GW}$, will be solar PV, while wind and concentrated solar power (CSP) will sum up to be $7.3 \mathrm{GW}$ [10]. By 2030, the figures will reach $40 \mathrm{GW}, 16 \mathrm{GW}$, and $2.7 \mathrm{GW}$ for solar PV, wind, and CSP, respectively. This target covers about $32 \%$ of the current KSA peak power consumption (2018 estimate) of $61.743 \mathrm{GW}$ [12]. This high level of solar generation is achievable due to the significant reduction in the cost of solar PV [13]. The government is expected to initiate legal and regulatory frameworks for the deployment of renewable energy resources and the harnessing of private sector investment and encouraging public-private partnerships.

Solar PV technology has been long established in Saudi Arabia. In 1977, KSA and the United States of America (USA) started a joint collaboration (Solar Energy Research American and Saudi) aimed at developing solar energy technologies for the mutual benefit of both countries. This was followed by another joint program in 1986 with Germany (HYSOLAR), a cooperative undertaking for research, development, and demonstration of solar hydrogen production, as well as utilization of hydrogen as an energy carrier [14, 15]. Since then, the academic community of the country has carried out many research and development (R and D) projects and participated significantly in the international $\mathrm{PV}$ society. Although it still has limited manufacturing capacity for PV value-chain components, the Saudi PV industry is expected to become the leading market in the region in $\mathrm{PV}$ grid connected projects in the next several years [11]. Consequently, all industries related to solar technology shall be gradually localized. However, localization of the PV industry in KSA may encounter more economic problems than the world leaders in the PV value chain. Other countries that are prioritizing localization of manufacturing have used governmental support programs through political regulations and tax incentives, to facilitate localization of the industry $[16,17]$. Such programs also resulted in job creation and development of human capital, which are also major goals for Saudi Vision 2030. To the best of our knowledge, the present study is the first analysis of the opportunities for localization of the PV industry in the KSA. This paper briefly reviews current PV technology and its supply chain and discusses the major issues impacting the localization of the Saudi solar PV industry considering the available local resources and industries.

Fig. 1 Renewable energy targets for the KSA over the next 5-12 years 


\section{PV industry value chain}

Solar PV systems are classified according to their lightcollection mechanism: flat plate or concentrated PV (CPV), where the former is the most common. CPV has been shown to reach very high efficiency of above $40 \%$ [18]. However, it requires sophisticated solar-tracking systems and does not operate well in dusty and foggy environments (where the required direct normal-incident solar radiation is limited). For this reason, CPV is only a small part of the KSA energy mix. Each technology has advantages and disadvantages in terms of efficiency, ease of manufacture, and degradation. Crystalline silicon solar cells are still the most commonly used technology in the solar industry and are generally less expensive than the other types of cells [19]. Polycrystalline silicon (poly silicon) PV technology is the main focus of this paper since it currently represents more than $90 \%$ of the commercial PV systems in the world [20]. In this section, the main steps in the value chain of the poly-silicon based PV industry are discussed to provide a background for the analysis of the localization of this process in KSA.

\section{Polycrystalline silicon production}

Polycrystalline silicon is manufactured from silica, one of the most abundant elements on Earth, the primary raw material in the value chain of the PV industry. The first step in the production process is converting quartz sand into metallurgical-grade silicon, which is purified into solar-grade silicon that is suitable for producing silicon wafers. The global production of polycrystalline silicon increased from 235,000 tons in 2014 to about 453,000 tons in 2016 [2]. Semiconductor industries used only $10 \%$ of the total production in 2015 , indicating that the PV industry became the largest consumer of polycrystalline silicon in recent years.

A significant shortage in the supply of silicon due to an increase in the demand from both the PV industry and semiconductor manufacturers in 2008 resulted to a price increase of up to US $\$ 500 / \mathrm{kg}$. This price gradually went down to US $\$ 13 / \mathrm{kg}$ at the end of 2015. This huge drop was attributed to increased production rate and the emergence of new manufacturers in the market [21]. However, many PV module manufacturers signed long-term supply contracts at higher costs during the supply shortages, which are still affecting the costs of PV modules today.

The conventional methods for polycrystalline silicon production are the Siemens process and the fluidized bed reactor (FBR) method. The Siemens process uses huge amounts of energy to superheat silicon gas and deposit pure silicon on seed-silicon rods inside a huge refrigerator, while the FBR method uses granules of purified Si instead of seed rods. The consumption of energy during the Siemens process has decreased from $80 \mathrm{kWh} / \mathrm{kg}$ in 2010 to $55 \mathrm{kWh} / \mathrm{kg}$ in 2015; however, the FBR process still consumes less energy. Among the two fabrication methods, the metallurgical process that produces polycrystalline silicon directly from metallic silicon has the lowest energy consumption and, hence, cost. This has led to companies from countries such as Canada, the USA, and Norway to focus on this method [22].

China is the global leader, producing over $50 \%$ of the polycrystalline silicon worldwide, which is entirely consumed domestically. Despite this high level of production and concerns of domestic silicon quality, Chinese manufacturers need to import high-quality poly-silicon raw materials from countries such as Germany, Korea, and Malaysia [22]. In KSA, where sand is one of the most abundant materials and the country's ambitious vision involves maximizing local production, polycrystalline silicon production is being localized via the private sector. Some specialized companies have recently started to convert silica-rich sand into polycrystalline silicon. The Polysilicon Technology Company located in Jubail city (located in the eastern province) was the first to contribute to this industry by investing in a factory with a 3000 metric ton capacity that uses the hydro chlorination-Siemens process. In addition, King Abdulaziz City for Science and Technology (KACST; KSA) is collaborating with Stanford Research Institute (SRI; USA) to transfer knowledge and technology developed at SRI regarding the $\mathrm{SiF}_{4}-\mathrm{Na}$ process to provide high-purity silicon with the objective of designing, building, and operating a pilot plant.

\section{Ingots and wafers}

The production of ingots and wafers is the second step of the PV manufacturing value chain. The highly purified polycrystalline silicon is used to make single-crystalline silicon ingots or multi-crystalline silicon (mc-Si) ingots. The first type is used for both the microelectronics and PV industries, whereas the second is used only for the PV industry. The most common process for producing single-crystal ingots is the Czochralski method, which involves pulling molten silicon upward under rotation and forming a cylindrical singlecrystal ingot. The wafers cut from these ingots have regular and perfectly arranged crystals. On the other hand, the manufacturing of -Si ingots uses a furnace to convert molten silicon into cast ingot blocks, which are slowly cooled, resulting in the formation of multiple small crystals in the blocks. The mc-Si ingot blocks are then sliced into wafers of thickness of about $150 \mu \mathrm{m}$. Finally, the wafers are cleaned and polished before being inspected [23]. Around $60 \mathrm{GW}$ of wafers were produced in 2015, where China dominated the global market 
with $\sim 80 \%$ of the total production [19]. To date, the ingot and wafer industries have not been introduced into the KSA. However, they are expected to be among the main targeted industries for PV component localization in the coming few years.

\section{PV cells}

Wafers usually have some damage after slicing; hence, both surfaces of the wafer need to be etched using a wire saw to remove defects. Texturing of the wafer surface is also performed to minimize reflection of incident solar radiation (by more than 70\%). Amorphous silicon (A-Si) can be textured using random chemical texturing, while mechanical texturing is used for multi-crystalline silicon ( $\mathrm{mc}-\mathrm{Si}$ ) due to its crystalline structure. Subsequently, impurity dopants are implanted into the wafers to form the $\mathrm{p}-\mathrm{n}$ junctions. This process is usually performed in high-temperature furnaces, although screen printing and chemical vapor deposition can also be used [24, 25]. Then, the front and rear sides of the wafer are electrically isolated and an anti-reflection coating is applied to further reduce light reflection and maximize solar absorption.

The metallization process for forming the metal contact is an important step in cell manufacturing, because the cell properties, such as short-circuit current, open-circuit voltage, and fill factor, strongly depend on the quality of this contact. Front-side (sun side) contacts are the most widely used, back side contacts result in better overall performance. Cells with back metallization have several advantages: (1) the absorption area is not shadowed by the contacts, resulting in 5\% higher power compared to the standard PV module; (2) simple cell assembly that requires $30 \%$ less manpower than the standard PV module assembly, which results in lower manufacturing costs [26, 27], and (3) $4{ }^{\circ} \mathrm{C}$ lower nominal operating cell temperature that increases cell conversion efficiency [28].

Considering these production methods, KACST is operating a cell metallization process line with a 100-MW yearly output, which is feeding a 100-MW module production line. This facility uses double-printing technology for front printing, the most advanced screen printing process for manufacturing solar cells. This technology reduces the use of printing pastes (e.g. silver and aluminum) by up to $30 \%$ compared to the standard screen printing method. In addition, narrow finger widths of the contacts can be achieved, which results in a lower shadowing area, and hence, more photons are captured by the cell, which increases the overall cell efficiency. Production started in 2016, where KACST imported semifinished solar cells (after anti-reflection coating) to test the metallization process. The front-side contacts are produced by screen printing silver, while the back side of the solar cell is coated with aluminum, and a mixture of silver and aluminum is used for bus bar printing. KACST operates its own $\mathrm{R}$ and $\mathrm{D}$ back-contact assembly line. Back side printing is achieved by printing metal pastes with special screen printing device that place the metal inline onto the back side.

Moreover, the double-printing (DP) concept is now being investigated in the KSA. KACST has implemented this concept, a new multi-printing technology, which can achieve finer printed features and enhanced the cell electrical performance. The layout of the front contacts of a solar cell needs to be designed considering a trade-off between increasing the current-carrying capability of the contacts by increasing the cross section of the metalized lines, while minimizing the shaded area on the sun side of the cell to maximize photon collection. In the DP process, the second layer of paste is screen printed on top of the first one with high alignment accuracy using a high-precision printer. In this way, the aspect ratios (i.e., the ratio of line height to line width) of the printed lines can be increased, which increases the current-carrying capacity of the contacts, while minimizing shading. In addition, fewer finger interruption defects are observed in DP cells compared to single screen printed cells.

\section{PV modules}

Most assembly lines for crystalline silicon modules are located close to cell manufacturing factories. It is strategically advantageous to locate module assembly lines close to end users to avoid exporting bulky and heavy materials such as glass and aluminum frames. In the assembly of modules, a number of PV cells (generally 10 or 12 cells) are connected in a series to form a string. A group of strings (generally six strings) are connected in series to form the fundamental unit of the PV module. This unit is laminated between two sheets of ethylene vinyl acetate (EVA), which is encapsulated using a special type of glass at the front and a polymeric sheet at the bottom, and then framed with anodized aluminum bars. Finally, a junction box is fitted to the rear of the module $[24,25]$.

In 2015, $63 \mathrm{GW}$ of PV modules were produced, where China was the largest producer (69\% of total production). The KSA is targeting $58.7 \mathrm{GW}$ of renewable energy by 2030 under Saudi Vision 2030 [10]. Even though the country has impressive natural potential for solar and wind power and local energy consumption is expected to be doubled by 2030 , a competitive renewable energy sector is lacking at present. To develop this sector, the ministry of energy has set an initial target of generating $27.3 \mathrm{GW}$ of electricity from renewables by 2023 , while aiming to localize a significant portion of the renewable energy value chain in the Saudi economy, including $\mathrm{R}$ and $\mathrm{D}$ and manufacturing.

The project plan for solar PV in the KSA has been finalized and execution of the first stage began in 2018, with a target of $2.22 \mathrm{GW}$ by the end of 2019 , reaching $40 \mathrm{GW}$ 
by 2030 [10]. These projects coincide with the launch of the National Industrial Development and Logistics Program (NIDLP), which is one of twelve programs of Saudi Vision 2030. The program is focused on transforming the KSA into an industrial powerhouse and a global leader in logistical services. It will lead and guide the growth of four key sectors: industry, mining, energy, and logistics, which are expected to contribute to the successful localization of manufacturing in these industries, which would generate ample job opportunities for Saudis, enhance the trade balance, and maximize local content. [29].

Some PV module assembly lines have been recently opened in the KSA, accounting for several hundreds of MW per year, to which the existing local glass, aluminum, and petrochemical industries will contribute by providing the required materials with high specifications. For example, the Saudi International Petrochemical Company (Sipchem) established a new EVA production facility (the Wahaj factory) in Hail city in the north of the KSA. The total capacity of this factory could meet the need for about $700 \mathrm{MW}$ of solar panels. They offer multiple EVA grades, where their fast-cure EVA and ultra-fast-cure EVA products could reduce the lamination time during solar cell production and increase the throughput of the assembly line.

\section{Inverters}

There are three main types of PV inverters: module-level micro inverters; string inverters (medium-scale inverters that power up to $100 \mathrm{KW}$ ); and central inverters (largescale inverters that power up to a few MW). For small-scale rooftop applications, micro and string inverters are used, while central inverters are used in utility-scale PV plants. The size and cost of new inverters are decreasing, while their efficiency is increasing due to the availability of advanced power semiconductor devices based on silicon carbide and gallium nitride. These improved devices provide more flexibility in terms of control and communications, allowing the inverters to contribute significantly to the development of reliable smart grids [30]. Saudi Arabia has a well-established infrastructure for the power electronic device industry. For example, the Advanced Electronics Company launched the new Shams PV inverter production line in September 2015 that can produce up to 2000 units or $1 \mathrm{GW}$ per year [31]. In addition, KACST has transferred and localized the design and manufacture of both micro and string inverters; it operates an assembly line that produces up to $50 \mathrm{MW}$ of string inverters every year.

\section{Balance of system}

The balance of system (BoS) refers to all other system components that are necessary to integrate the photovoltaic panels and inverter with the building load and/or the electric utility supply. Such components account for nearly half of the cost of a PV plant, whereas the PV modules and inverters represent the remaining half. Several components are needed for protection and energy supply conditioning such as:

- mounting structure and trackers

- wiring, for both the DC and AC portions of the system

- manual switches and automatic protection equipment

- structures or solar trackers, where the solar PV modules are mounted.

Energy storage is required for stand-alone or off-grid systems. An off-grid solar system must be designed appropriately so that it will generate enough power throughout the year and have enough battery capacity to meet the home's requirements. Battery bank and charge controllers are parts of the BOS of this system. More complex solar PV systems may include elements such as a solar-tracking system, a weather station, a sophisticated computing system for automated operation and for data monitoring and recording. For utility-scale installations it may also include a substation and transformer bank to supply their output to the electric grid. Nearly $50 \%$ of utility-scale PV plants being built are equipped with single-axis tracking systems, as they increase the output power of the plant by about $20 \%$, with less than a $10 \%$ increase in the cost [22]. Most of the basic industries required to produce the BOS components are available in the KSA and they could immediately participate in manufacturing many of the required components. For example, cable producers, steel industries, and installation contractors are well established and eager to enter this growing field of business.

\section{Operation and maintenance}

With the continuous global growth of PV systems, the operation and maintenance ( $\mathrm{O}$ and $\mathrm{M})$ of these systems are vital and should be taken into consideration. The lifetime of a $\mathrm{PV}$ plant depends greatly on the reliability of the $\mathrm{O}$ and $\mathrm{M}$ procedures, whether for small-scale solar applications or for utility grid applications. These are tasks and processes that include monitoring, preventive maintenance, corrective maintenance, and facility management. The monitoring process is a list of "to do" list during normal operation. For residential and small-scale applications, the micro inverters have all the automatic features that human interference is at the minimum. It monitors and stores all the electrical parameters that are required for automated operation from sunrise to sunset, real time. For utility grid connected and stand-alone solar power plants, automated and instrumentation data acquisition systems are integrated into it. Manual mode is also incorporated in the systems' operation mode 
for the purposes of troubleshooting and repair. AC and DC voltages and currents are monitored for the automation decision process. Preventive maintenances are activities that are comprised of regular visual and physical inspections and verification activities and inspection of certain electrical and mechanical components and all other key components conducted with specific frequencies of which are necessary to comply with the operating manuals and recommendations issued by the original equipment manufacturers (OEMs). Corrective maintenance covers troubleshooting and repair. It is done to restore a PV plant system, equipment or component to a status, where it can perform to its required function. It usually takes place when the remote monitoring and supervision system detects a failure. Malfunction detection can also occur during regular inspections and specific measurement activities. The main consideration of this activity is the time spent to restore full operational mode. Finally, facility management refers to the overall management of the process and the site [32]. It means meeting the full performance capacity of the power plant. This can be achieved by effective implementation of $\mathrm{O}$ and $\mathrm{M}$ procedures. Reports coming from various PV system groups around the world have estimated different $\mathrm{O}$ and $\mathrm{M}$ costs. However, the estimation from the US Department of Energy (DOE) National Renewable Energy Laboratory (NREL) Solar Access to Public Capital (SAPC) working group proposed that $\mathrm{O}$ and $\mathrm{M}$ costs compose around $0.5 \%$ of the initial cost per year for large systems and $1 \%$ of the initial cost per year for small systems, including the replacement of failed inverters [33]. Considering the harsh environments in the KSA, such as heavy dust and high temperatures, these costs could be higher.

\section{PV industry localization in KSA}

Saudi Arabia is aiming to reduce its domestic reliance on fossil fuels as it pursues its Saudi Vision 2030 plan of diverse economic and social objectives. Its vision is to reduce dependence on industrial imports by building substantial local industries to serve the economy and with the future aim of becoming an exporting nation. This aim to become self-sufficient in manufacturing solar components is potentially achievable due to the local availability of most of the raw materials for the entire value chain. In addition, expertise in consultancy, administration and planning, and the production of solar cells, modules, inverters, tracking systems, mounting systems, and cabling is locally available. The country has a sufficient body of researchers and major public sector laboratories and workshops for all parts of the PV supply chain such as public sector institutions (e.g., KACST). Effective collaboration between such institutions, coupled with government policies that prioritize renewable products, is expected to enhance the morale of the local PV industry and drive development. Local jobs are expected to start flourishing in KSA in many fields related to the PV sector such as manufacturing, project development, sales and marketing, and installation. Much consideration is given to residential power systems, the prospected major market, if policies, tariffs and regulations are instituted.

This study depends on two solid localization experiences. First is a $10 \mathrm{MW}$ PV plant that has been built in Khafji city as a part of the national initiative of water desalination using solar energy. Although this project is small, it gave the authors who were leading project execution team, a good understanding of the percentage share of each part of the system as shown in Fig. 2a. Moreover, this PV plant gives a good perspective of the potential localization of a PV project parts. Second experience is the local PV module assembly line that was established in KACST in 2010 with 3 MW capacity and was expanded recently to a capacity of 100 MW of PV modules every year. From this assembly line, the real numbers regarding PV module components can be used as shown in Fig. $2 b$ and consequently, the potential of localization of each component will be predicted.

During the course of this study and in conjunction with the $10 \mathrm{MW}$ project that was accomplished in 2018 and KACST PV assembly line, it was estimated that a total of nearly $45 \%$ of solar energy components were supplied locally, where the percentages of locally supplied components for each part category is shown in Fig. 3a. It can be seen that in the civil work and electrical field, manpower
Fig. 2 Breakdown of costs in the a PV industry for a 10-MW system and $\mathbf{b}$ a PV module of the system (a)

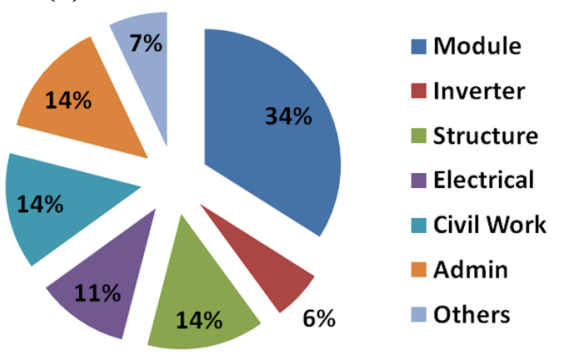

(b)

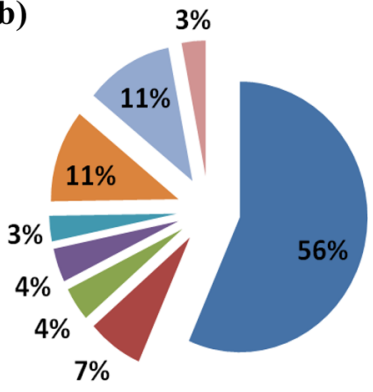

- Solar Cell

- Solar Glass

EVA Sheet

Backsheet

- Junction Box

Aluminum Frame

Manufacturing Cost

- Others 


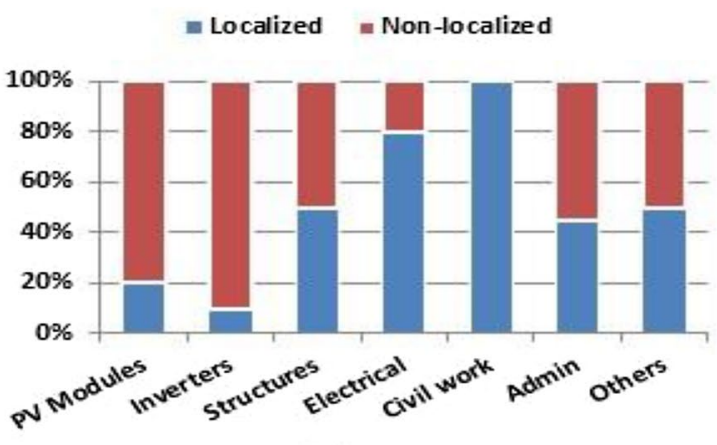

(a)

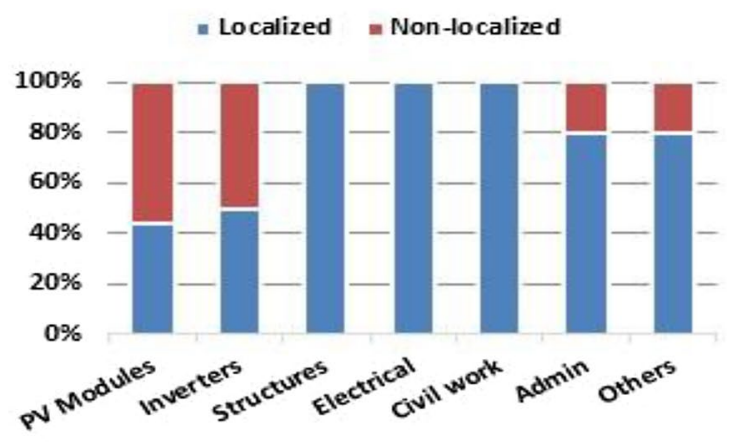

(b)

Fig. 3 Components of the PV value chain a supplied locally and externally in 2018 and $\mathbf{b}$ anticipated values for 2023

and material supply, comes from domestic produce. Material supplies in the other sectors are dependent on external providers. Note that the supply of inverters is less than $10 \%$, the lowest among the local share. Distribution of shares of the PV system ranges from $20 \%$ for modules to $80 \%$ for electrical work. Hence, the civil and electrical works showed the highest local availability, as these industries are already well established in the local market of the KSA. On the other hand, the inverters and PV cells are still mostly sourced internationally, as these are still newly developing industries in the Saudi market.

The growth of localization of the PV industry in Saudi Arabia is being anticipated, as the government will promote the increase of renewable energy as part of the domestic energy mix for electricity generation, by adding substantial amount of renewable energy in the future. Based on KACST's experience in the PV industry in the KSA, this paper predicts the growth of localization of the industry sections, as summarized in Fig. 3b. With many players in each sector of the industry progressing rapidly, electrical and structural works are expected to be completely localized within a few years. The mid-paced developments in administration and "others" segments of the PV industry are expected to be around $80 \%$ localized by 2023 . While $\mathrm{PV}$ module localization is expected to reach about $43 \%$ as all parts in Fig. 2b can be localized except solar cells, as discussed previously in the second section of this paper.

The administration and "others" sections include managerial, intellectual, and consultancy field along with needed specialized tools and equipment, facilities, spares, and welltrained staff and personnel. The development of these fields would result in major knowledge and technology transfers into the industries. The most challenging localization sectors would be the PV module and inverter manufacturing side. These two sectors are being encouraged to achieve a remarkable growth of around $50 \%$ by the end of the 2023 fiscal year. These fractions of localization could increase even further, if the emerging policies for developing the renewable sector are implemented successfully with a minimum cumulative growth prediction of $75 \%$ by 2023 .

The sincere attempts of KSA to diversify its economy away from the reliance on petroleum production would accelerate the PV industry localization process. Predicting these values in more detail is complicated due to uncertainties related to the implementation of future policies and regulations that could greatly affect these values. We hope that these predicted values can be used as a baseline for policy development and promoting collaboration within supply chain industries and research facilities.

This study is an initial step toward predicting and facilitating localization of the PV industry in the KSA. An increase in the level of PV localization is perfectly aligned with the KSA's ambitious plans regarding renewable energy implementation and it is expected to create a significant number of jobs. Citing reports from the International Renewable Energy Agency and their annual review of jobs in 2017 [34], 10.3 million people were employed in the renewable energy field (including hydro power) in 2017, with an increase of 5.3\% since 2016. China, Brazil, the United States, India, Germany, and Japan have remained the world's biggest renewable energy employers, representing more than $70 \%$ of such jobs. The PV industry is the largest employer in the renewable energy field, with 3.4 million jobs (an increase of $9 \%$ from 2016) reflecting the year's record $94 \mathrm{GW}$ of PV installation.

The Renewable Energy Project Development Office (REPDO) of Saudi Arabia's ministry of energy announced in [35] that seven projects of a total capacity of $1.51 \mathrm{GW}$ of solar PV are in the process of bidding. These seven projects are expected to create 4500 jobs during construction and $\mathrm{O}$ and $\mathrm{M}$ [35]. Based on REPDO employment data, it can be predicted that about 60,000 jobs will be created by 2023 as $20 \mathrm{GW}$ of PV projects are planned to be built.

The significant increase in employment in the PV field is expected to follow the same trend as that of the large growth of the petrochemical industry, which was established 
in the KSA in the 1980s. However, some unemployment is expected as a result of inertia to change in some conventional power industries that could be eliminated by PV power. This may lead to some experts changing industries to fill newly created jobs, which will affect the analysis of PV job creation.

Moreover, the maturity of PV manufacturing technology and the economies of scale will influence the number of jobs created, as some jobs will likely be replaced with automated equipment in state-of-the-art manufacturing plants [36]. Therefore, a well-designed plan needs to be implemented by the Saudi entities, including the ministry of labor (job creation), ministry of education (solar training and education), ministry of finance (budget allocation), and the Saudi electricity company (off-taker) to achieve the potential $75 \%$ localization by 2023 . This localization could revolutionize wide sections of the economy, resulting in socioeconomic and industrial progresses.

\section{Conclusion}

The ambitious Saudi Vision 2030 plan aims to increase the participation of private industry in the economy and reduce the national dependence on oil. This provides opportunities for accelerated implementation of renewable energy systems (in particular solar energy) in the future. Analysis of the value chain of the solar PV industry showed that a large portion of this industry could be localized within the KSA in alignment with Saudi Vision 2030, which states that 20.0 GW from solar PV will feed the national grid by 2023 . It is predicted that localization of the solar PV industry will increase from $45 \%$ in 2018 and close to $75 \%$ in 2023 , allowing the private sector to participate substantially in the national economy. These values could increase further; even reaching full localization, in response to recently announced plans for the largest PV power project in the world with a capacity of $40 \mathrm{GW}$ to be installed across the KSA by 2030 . However, the integrity of these predictions depends on the strength and timeliness of the localization policy framework that the government applies. Detailed analysis of the localization of the PV industry is a complex task. Hence, it is recommended that further detailed studies considering the economics of localization are undertaken in the future. The findings of this preliminary study have several shortcomings due to the limited available data regarding PV projects in the KSA. However, the study provides some new perspective for Saudi decision makers and highlights the importance of developing the local PV industry and its potential impact on employment. As many countries are beginning to transition from petroleum-based economies to those utilizing more renewables, it is expected that this study is broadly relevant, especially in the MENA region, where solar PV is likely to be the main source of renewable energy.

Funding This work was supported by internal funding from the King Abdulaziz City for Science and Technology.

Open Access This article is licensed under a Creative Commons Attribution 4.0 International License, which permits use, sharing, adaptation, distribution and reproduction in any medium or format, as long as you give appropriate credit to the original author(s) and the source, provide a link to the Creative Commons licence, and indicate if changes were made. The images or other third party material in this article are included in the article's Creative Commons licence, unless indicated otherwise in a credit line to the material. If material is not included in the article's Creative Commons licence and your intended use is not permitted by statutory regulation or exceeds the permitted use, you will need to obtain permission directly from the copyright holder. To view a copy of this licence, visit http://creativecommons.org/licenses/by/4.0/.

\section{References}

1. McCrone, A., et al.: Global Trends in Renewable Energy Investment 2016. Frankfurt School-UNEP Centre and Bloomberg New Energy Finance Report, Frankfurt School of Finance and Management (2016)

2. Energy Information Administration (EIA): International Energy Outlook 2016 With Projections to 2040. Statistical report U.S. energy information administration office of energy analysis U.S. Department of Energy. Washington, DC. (2016)

3. Renewable Energy Network Policy for the 21st Century (REN21): Renewables 2016 global status report (2016)

4. European Commission's Communication: Energy roadmap 2050. European Union, 2012, Report, ISBN 978-92-79-21798-2 (2011)

5. European Commission's Communication: A policy framework for climate and energy in the period from 2020 to 2030. Brussels, (2014)

6. Li, F.G.N., Trutnevyte, E.: Investment appraisal of cost-optimal and near-optimal pathways for the UK electricity sector transition to 2050. Appl. Energy 189, 89-109 (2017). https://doi. org/10.1016/japenergy.2016.12.047

7. Yang, X.J., Hu, H., Tan, T., Li, J.: China's renewable energy goals by 2050. Environ. Develop. 20, 83-90 (2016)

8. International Renewable Energy Agency. Renewable Energy Market Analysis: GCC 2019. https://www.irena.org/-/media/Files/ IRENA/Agency/Publication/2019/Jan/IRENA_Market_Analy sis_GCC_2019.pdf (2019)

9. Faruqui, A., Hledik, R., Wikler, G., Ghosh, D., Prijyanonda, J., Dayal, N: Bringing demand-side management to the Kingdom of Saudi Arabia: Final Report. The Brattle Group, pp. 40 (2011)

10. Alsheri, T.: Saudi Arabia National Renewable Energy Program. Power Point Presentation, Mineral Resources (MEIM), Renewable Energy ProjectDevelopment Office (REPDO) (2019)

11. Saudi Arabia Solar Industry Association (SASIA). Country Focus Report (2017). https://www.solar-united.org/wp-content/uploa ds/2017/02/SASIA-CountryFocusReport-SP.pdf

12. Argaam: Power consumption in Saudi Arabia hits peak level in 2018. (2018)

13. Dipaola, A.: Saudi Arabia to revive its solar power program at smaller scale. Blomberg Business (2016)

14. Sayigh, A.A.L.I.: Photovoltaic powered villages in Saudi Arabia", IEE Science, Education and Technology Division, "Colloquium 
on Energy for Isolated Communities. University of Reading, Reading (1988)

15. Grasse, W., Oster, F., Aba-Oud, H.: HYSOLAR: "The GermanSaudi Arabian program on solar hydrogen-5 years of experience". Int. J. Hydrogen Energy 17(1), 1-7 (1992)

16. Kuntze, J.-C., Moerenhout, T.: Local content requirements and the renewable energy industry - a good match. International Centre for Trade and Sustainable Development, Geneva (2015)

17. Kolstad, I., Kinyondo, A.: Alternatives to local content requirements in resource-rich countries. Oxford Dev. Studies 45(4), 409-423 (2017)

18. Chukwuka, C., Folly, K.A.: Overview of concentrated photovoltaic (CPV) cells. J. Power Energy Eng. 2, 1-8 (2014). https://doi. org/10.4236/jpee.2014.211001

19. Sharma, S., Jain, K.K., Sharma, A.: Solar cells. Research and applications-a review. Mater. Sci. Appl. 06(12), 1145-1155 (2015)

20. Mulvaney, D.: Photovoltaic (PV) Industry Primer Overview of PV manufacturers, technologies, supply chains, performance standards and certifications. Report prepared for Green Electronics Council (2015)

21. International Energy Agency: Photovoltaic power systems programme report: trends in photovoltaic applications 2015. Report IEA PVPS T1-27. http://www.iea-pvps.org/fileadmin/dam/public/ report/national/IEA-PVPS_-_Trends_2015_-_MedRes.pdf (2015)

22. International Energy Agency: Trends 2016 in photovoltaic applications. Survey Report of Selected IEA Countries between 1992 and 2015, EA PVPS, IEA PVPS T1-30 (2016)

23. Fisher, G., Seacrist, M.R., Standley, R.W.: Silicon crystal growth and wafer technologies. Proc. IEEE 100, 1454-1474 (2012)

24. Xakalashe, M.A., Tangstad, M.: Silicon processing: from quartz to crystalline silicon solar cells. S. Afr. Inst. Mining Metal. 2011, 83-87 (2011)

25. Saga, T.: Advances in crystalline silicon solar cell technology for industrial mass production. NPG Asia Mater. 2, 96-102 (2010)

26. Bidiville, A., Wasmer, K., Kraft, R., Ballif, C.: Diamond wire sawn silicon wafers-from the lab to the cell production. 24th
European Photovoltaic Solar Energy Conference and Exhibition, Hamburg, Germany, September 2009, pp. 21-25

27. Fossum, J.G., Sarkar, D., Mathew, L., Rao, R., Jawarani, D., Law, M.E.: Back-contact solar cells in thin crystalline silicon. 35th IEEE Photovoltaic Specialists Conference, pp. 003131-003136.

28. Wu, Y., et al.: Metal wrap through silicon heterojunction solar cells and first made minimodules. 29th European Photovoltaic Solar Energy Conference and Exhibition, Amsterdam, The Netherlands, September 2014, pp. 475-480

29. National Industrial Development \& Logistics Program (NIDLP): Delivery plan 2018-2020. https://www.argaam.com/en/article/ articledetail/id/591828 (2018)

30. Bowden, S.: From the valley of death to the golden decade: crystalline silicon solar cells from 10 to 100/lm. In: 9th Workshop on Crystalline Si Solar Cells and Modules (2009) p. 192

31. South African Photovoltaic Industry Association, SAPVIA. AEC and KAKO New Energy Launch Inverter Production in Saudi Arabia. https://www.sapvia.co.za/aec-and-kaco-new-energy-launc h-inverter-production-in-saudi-arabia. Accessed 21 Sept 2015

32. Haney J., Burstein A.: PV system operations and maintenance fundamentals. Solar America board for codes and standards. Report, August (2013)

33. Keating, T.J., Walker, A., Ardani, K.: SAPC best practices in PV operations and maintenance, version 1.0. Period of Performance January 1, 2014-December 31, 2015 (NREL report) (2015)

34. International Renewable Energy Agency: Renewable energy and jobs, annual review 2018. https://irena.org/-/media/Files/IRENA/ Agency/Publication/2018/May/IRENA_RE_Jobs_Annual_Revie w_2018.pdf (2018)

35. Saudi Arabia's Ministry of Energy, Industry and Mineral Resources: Round two of renewable energy program. https:// www.powersaudiarabia.com.sa/web/attach/news/Press-relea se_29.01.2019_REPDO_EOI_RoundTwo.pdf (2019)

36. Wei, M., Patadia, S., Kammen, D.M.: Putting Renewables and energy efficiency to work: how many jobs can the clean energy industry generate in the US? Energy Pol. 38(2), 919-931 (2010) 